\title{
DETERMINANTS OF BANK PROFITABILITY: EMPIRICAL EVIDENCE FROM A PACIFIC SMALL ISLAND DEVELOPING STATE
} Bimal Krishna $^{1 *}$, Shiu Lingam ${ }^{2}$, Anjani Mala ${ }^{3}$, Rajit Sen ${ }^{4}$

${ }^{1 *}$ Head of School, School of Economics and Finance, Fiji National University, Fiji; ${ }^{2}$ Lecturer, Department of Accounting, Fiji National University, Fiji; ${ }^{3}$ Lecturer, Department of Banking and Finance, Fiji National University, Fiji; ${ }^{4}$ Lecturer, Department of Economics and Customs, Fiji National University, Fiji. Email: ${ }^{1 *}$ bimal.krishna@fnu.ac.fj, ${ }^{2}$ shiu.lingam@fnu.ac.fj, ${ }^{3}$ anjani.mala@fnu.ac.fj, ${ }^{4}$ rajit.sen@fnu.ac.fj

\author{
Article History: Received on $25^{\text {th }}$ February 2021, Revised on $20^{\text {th }}$ April 2021, Published on $1^{\text {st }}$ May 2021
}

\begin{abstract}
Purpose: This study aims to investigate the determinants of profitability of the Fijian banks for the 2001-2019 periods. Using several bank-specific and external variables, and covering nineteen years, researchers measure the impact of each variable on Return on Average Assets, Return on Average Equity, and Net Interest Margin.

Methodology: The sample of this study comprises five commercial banks and two credit financiers. Purposive sampling is employed resulting in 133 audited financial statements. Stata version 16 is used for multivariate econometric analysis and hypothesis testing.

Main Findings: The results of this research show that bank size, risk, and exchange rate positively impacts bank profitability while management efficiency, broad money supply, and quality of regulation negatively affect profitability. On the other hand, the level of liquidity, economic growth, and inflation do not have any impact on profitability.
\end{abstract}

Application of this study: The findings of this study can be of significance for regulators as well as financial institutions in policy development and market oversight to ensure the sustainability of financial institutions.

Novelty/Originality of this study: Few studies have so far been carried out on the banking sector in Fiji with only one focusing on profitability determinants. This study, using accounting financial ratios and several macroeconomic variables is unique in the sense that it uses several external variables not considered previously.

Keywords: Bank Profitability, Financial Performance, Financial Institutions, Pacific Small Island Developing State.

\section{INTRODUCTION}

The banking system plays a pivotal role in mobilizing financial resources from those with surpluses to those who need funds for various purposes and, as such, are central to the efficient operation of any economy. Their primary function involves accepting deposits and converting them into productive investments. In this context, the banks' intermediary role of fund providers is central to the economic well-being of any country. Therefore, the sustainability of banking institutions is very crucial in ensuring that they can continuously perform this primary role, (Tektas et al., 2005).

Consequently, the financial performance of banks has attracted the attention of many stakeholders in every country, including academics, policymakers, financial analysts, and regulators. This has led to an extensive number of empirical studies investigating the determinants of bank profitability using linear multivariate models, including, but not limited to, Smirlock (1985), Bourke (1989), Molyneux and Thorton (1992), Mansur et al. (1993), Miller and Noulas (1997), Hassan and Bashir (2012), Goddard et al. (2004) and Khediri and Ben-Khedhiri (2011). All these, and many others, have attributed bank profitability to bank-specific and macroeconomic factors. While banks have some control over internal factors since these are related to managerial decision-making, macroeconomic determinants (that may have a substantial influence on their profitability) remain out of their control. Therefore, it is important to study the impact of a range of variables on bank profitability.

\section{The Fijian banking sector}

The Fijian commercial banking sector consists of six commercial banks of which five are foreign-owned and one is locally owned. The first commercial bank in Fiji, the Bank of New South Wales, commenced its operations in 1901 and changed its name to Westpac Banking Corporation Limited (Westpac) after a merger with the Commercial Bank of Australia in 1982. Australia and New Zealand Banking Corporation (ANZ) opened its doors for business in 1953 and was later joined by the Bank of Baroda (BOB) established in 1961, the Bank of the South Pacific (BSP) established in 1996, and the BRED Bank, established in 2012. The only local bank, the Home Finance Company Bank (HFC), which initially set up its operations as a home lending facilitator in 1962, commenced commercial banking services in 2014. There are four credit financial institutions in Fiji including Credit Corporation (CC) established in 1992, the Merchant Finance and Investment Company Limited (MF) established in 1986, the Fiji Development Bank, established in 1967, and Kontiki Finance Limited (KFL), established in 2015.

\section{Objectives of the study}

The central aim of this study is to determine the level and significance of bank-specific and macroeconomic factors on the profitability of the banking sector in Fiji over 19 years, from 2001-2019. 
The main proxy used to measure bank profitability is Return on Average Assets (ROA) while Return on Average Equity (ROE) and Net Interest Margin (NIM) measures are used as comparisons. The findings of this study can be of significance for regulators as well as financial institutions in policy development and market oversight to ensure the sustainability of financial institutions.

\section{LITERATURE REVIEW AND HYPOTHESIS DEVELOPMENT}

The notion of profit is an underlying concept emanating from the wealth maximization objective of setting up a business (Friedman, 1970; Jensen, 2001). Profit can be seen as the residual income after all the costs have been deducted from the total revenue in a particular accounting period, in other words, it is an excess of total revenue over total expenditure. Profitability, then, would refer to the ability of a business to generate this excess. Many indicators have been used to measure this and, principally, three measures are quite common in banking literature including ROA, ROE, and NIM. ROA is calculated as the ratio of net income to total assets, ROE is computed as the ratio of net income to total equity, and NIM is calculated by dividing the net interest income by total assets.

According to Hassan and Bashir (2012), ROA measures the efficiency with which the management employs the assets for the bank to generate profits. Goddard et al. (2004) and Khrawish (2011) claim that ROA is a more accurate measure of a bank's performance, and the yearly averages of assets and equities are more relevant than year-end values. Consequently, we will use Return on Average Assets as the primary measure of bank profitability, however, Return on Average Equity and Net Interest Margin equations will also be estimated for comparability.

There are many internal (bank-specific) and macroeconomic factors affecting banks' performance as revealed by the extant literature from numerous studies carried out all over the world.

\section{Bank-specific factors}

\section{Liquidity ratio}

Another bank-specific variable that has had a significant impact on bank profit is the liquidity ratio, measured as the ratio of total loan to total assets. Higher liquidity is preferred, as it demonstrates the better ability of banks to manage their liquidity risks; however, holding more liquidity contributes to the higher opportunity cost of doing business (Godfrey, 2015). According to Bourke (1989), Abreu and Mendes (2002), Yao et al. (2018), and Al-Matari (2021), there is a positive and significant relationship between liquidity ratio and bank profitability. Similar conclusions have been drawn by Bashir (2003), Staikouras and Wood (2004), and Sultan et al. (2020). Conversely, Hakimi and Zaghdoudi (2017), based on a study of 10 Tunisian banks found a negative relationship between liquidity and bank performance. Godfrey (2015) and Farooq et al. (2021) also reported similar findings in the respective studies as well. Based on the studies confirming a positive relationship between the two variables we hypothesize:

\section{$\boldsymbol{H}_{1}$ : There is a positive relationship between liquidity ratio and performance.}

\section{Asset quality}

Asset quality refers to the robustness of the bank's loan portfolio which is measured as the ratio of loan loss provision to total loans. A lower ratio is preferred signifying that the bank has advanced loans to customers with better creditworthiness, thus, the chances of defaulting customers are quite low. This will also ensure that the total stock of loans carries lesser risk while contributing positively towards the financial performance of the banks. On the contrary, high levels of this ratio reflect poorly on banks' performance as it significantly increases loan loss provisions thereby increasing bad and doubtful debts, thus, contributing to poor bank performance. Consequently, asset quality is expected to have a negative relationship with bank performance. This is in line with the findings reported by Athanasoglou et al. (2008), Srairi (2009), Naceur and Omran (2011), Sufian (2009), Maiti and Jana (2017), Mendoza and Rivera (2017), $\underline{\text { Kadioglu et al. (2017), }}$ Yao et al. (2018) and Sultan et al. (2020). Based on the impact of bad and doubtful debts on risks, expenses, and ultimately on the net income, we hypothesize:

\section{$\mathrm{H}_{2}$ : There is an inverse relationship between asset quality and profitability.}

\section{Bank size}

In an earlier study, Alhadef and Alhadef (1964) found that there is a negative relationship between bank size and its growth. Similar findings have been reported by Kosmidou (2008), Berger (1995), and Farooq et al. (2021). On the other hand, Smirlock (1985), Goddard et al. (2004), Hoffmann (2011), Abdullah et al. (2014), Rahman et al. (2015), Hashem (2016), Gaber (2018), Sultan et al. (2020) and Kumar et al. (2021) reported a positive relationship between bank size and profitability. However, Quan et al. (2019) in their study of 10 Islamic banks in Malaysia found no significant relationship between bank size and profitability. Such diversity can be due to bank efficiency — beyond an optimal size it may create diseconomies of scale leading to a negative relationship, while smaller banks may become more efficient as they grow larger, thus it becomes a positive relationship, (Berger, 1995). We will use a firm-specific proxy for measuring bank size which is measured as the natural logarithm of total bank assets (Stikouras \& Wood, 2004). Due to 
the smaller size of the Fijian economy and a relatively smaller number of branches, customers and staff, we assume that diseconomies of scale for larger banks are not prevalent; hence, we hypothesize:

\section{$\boldsymbol{H}_{3}$ : There is a direct relationship between bank size and performance.}

\section{Management efficiency}

Management efficiency, measured as the ratio of total costs (expenses) to total income, indicates the ability of bank management to make sound financial decisions to reduce the average cost per dollar of income/sales. Thus, a key factor in the success and growth of any business, be it a bank or otherwise, is the management's responsibility to ensure that business assets are used in a way that generates revenue that maximizes firm value. This can be achieved via prudent controls on operating expenses that maximize profit. Obamuyi (2013) reported that efficient expenses management (lower operating expenses over profit ratio) has had a significant positive influence on the profitability of Nigerian banks. Similar results have been reported in Goddard et al. (2004), Gaber (2018), Abdullah et al. (2014), Khediri and Ben-Khedhiri (2011), and Kumar et al. (2021) in separate studies conducted on the banking sector of other countries. Sharma and Gounder (2012) in their study of the Fijian Banking sector from 2000 to 2010 found a positive and significant relationship between profitability and management efficiency, concluding that the banks are effectively able to pass on higher costs to their customers via higher margins, very similar to the findings reported by Ongore and Kusa $\underline{(2013)}$ in their study on the Kenyan commercial banks, thus we hypothesize:

\section{$\boldsymbol{H}_{4}$ : There is a positive relationship between management efficiency and performance.}

\section{Risk}

Risk is measured as the ratio of Total Equities over Total Assets and is expected to measure the amount of leverage used by banks to generate profits. A higher ratio reveals more capital and less leverage employed in generating revenue and vice versa, hence, a high ratio indicates low risk while a low ratio indicates a high-risk business model employed by banks. Abdullah et al. (2014), Sanni et al. (2020), and Kumar et al. (2021) found a positive and significant relationship between ROA and risk as well as between ROE and risk; thus we hypothesize:

\section{$\boldsymbol{H}_{5}$ : There is a positive relationship between risk ratio and bank performance.}

\section{Macroeconomic variables}

\section{Economic growth}

Growth in the level of Gross Domestic Product (GDP) is one of the key objectives of any economy as it is a measure of economic progress and development. Variations in the level of GDP are expected to affect levels of income and output in the economy, thereby increasing the demand for all kinds of financial products and putting upward pressure on interest rates (Pasiouras \& Kosmidou, 2007). Economic growth is also expected to have a positive impact on the bank's asset quality resulting in lower bad debts and doubtful debts. The study carried out by Staikouras and Wood (2004) on the European Union's banking industry found a significant and positive relationship between GDP growth rates and bank profitability. Similar results have been reported by Demirguc-Kunt and Huizinga (1999), Bourke (1989), Sultan et al. (2020), and Farooq et al. (2021). Sufian and Chong (2008) claiming that when an economy shrinks, the demand for financial products falls leading to a fall in profit margins. Thus we hypothesize:

$\boldsymbol{H}_{6}$ : There is a positive relationship between GDP growth rates and bank profits.

\section{Inflation rate}

Empirical studies into the effects of inflation on bank profit suggest a strong and inverse relationship between the two variables since inflation weakens the stability of the financial system as the real value of the bank's assets decreases. This is because the real value of payments made by debtors falls, causing significant financial distress to the creditor, especially if the unexpected rise in inflation has not been factored into lending rates. High inflation can also cause financial distress to the debtors as they may find it difficult to pay for a higher cost of inputs; labour costs may also rise as trade unions demand higher pay in light of the rising cost of living. As such Ayaydin and Aykut (2014), Yao et al. (2018), Quan et al. (2019), Sultan et al. (2020), and Farooq et al. (2021) found a significant and negative relationship between inflation and bank performance. Similarly, Tan and Floros (2012), Rahman et al. (2015), and Sahyouni and Wang (2019) reported that an anticipated rise in inflation may harm profit margins as interest rates on loans rise, resulting in loan defaults and premature terminations. Thus, we hypothesize:

\section{$\boldsymbol{H}_{7}$ : There is a negative relationship between inflation and bank profitability.}

\section{Exchange rate}

The review of recent literature reveals that many empirical studies have been carried out to study the relationship between exchange rate risk exposure and bank profitability. Manyok (2016), Elhussein and Onsma (2019), and Hossin and Mondol (2020) found a weak and negative relationship between exchange rate and banks' financial performance, however, Faroog et al. (2021) and Ozkan (2021) reported a strong negative relationship between exchange rate and 
return on assets. Also, Wong et al. (2008), in their study on Chinese banks, found that the stronger Chinese currency reduced banks' equity resulting in poor financial performance. The exchange rate values used in this study are the natural logarithms of real effective exchange rate index calculated from the exchange rate of Fijian dollar (FJD) to the following currencies: US Dollar (USD), Pound Sterling (STG), Australian Dollar (AUD), New Zealand dollar (NZD), Japanese Yen (Yen) and Eurodollar (EURO). Thus we hypothesize:

$\boldsymbol{H}_{8}:$ There is an inverse relationship between exchange rate and profitability.

\section{Money supply}

Money supply refers to the aggregate quantity of money available in an economy and is classified as M1, M2, and M3. M1, known as narrow money, includes cash and demand deposits; M2 is known as quasi-money and includes M1 plus savings deposits and money market instruments; M3 is known as broad money and includes M3 plus time deposits. According to Borio et al. (2017), it is expected that contractionary monetary policy will reduce money supply leading to a rise in interest rate resulting in higher net interest income, and vice versa. However, significantly higher interest resulting from large contractions in the money supply could lead to a significant rise in bad debts and provision for doubtful debts leading to a fall in bank profitability (Borio et al., 2017). However, Tabak et al. (2016) reported an insignificant impact on change in bank profitability due to changes in the money supply since it does not lead to an increase in loans and advances. Similarly, Uwazie and Aina (2015) reported that an increase in money supply will raise the level of commercial banks' loans and advances; however, this will be offset by a rise in inflation, liquidity ratio, and exchange rates, hence leading to erosion of any gains realized via lending activities. Thus, we hypothesize:

$\boldsymbol{H}_{9}:$ There is a positive relationship between money supply and profitability.

\section{Quality of regulation}

Recent research in corporate governance indicates the significance of country-level governance on firm performance, highlighting its implication on extenuating agency costs, hence, positively impacting firm performance (Ngobo \& Fouda, 2012; Nguyen et al., 2015). This can be due to the direct consequence of national-level governance in reducing transaction costs, cost of production, and mitigating risks (Nguyen et al., 2015). Nguyen et al. (2015), and Ngobo and Fouda (2012) found a positive and significant relationship between national-level governance and firm profitability. Also, Aguilera and Jackson (2010) and Filatotchev et al. (2013) suggest that national-level governance quality promotes better firm-level governance and thus promoting better financial performance. For this study, we use the regulatory quality index instead of an aggregate governance index as the proxy for national governance to assess the impact of strong/weak regulatory mechanisms on bank-level financial performance. Based on these the hypothesis is thus formulated:

$\boldsymbol{H}_{10}$ : There is a positive relationship between the quality of national regulation and bank profits.

Table 1: List of variables, their definitions, and the expected relationship

\begin{tabular}{|c|c|c|c|}
\hline Acronym & Variable & Proxy & Expected relationship (+/-) \\
\hline \multicolumn{4}{|c|}{ Dependent Variable } \\
\hline ROA & Return on Average Assets & Net Income/ Average Total Assets & \\
\hline ROE & Return on Average Equity & Net Income/ Average Total Equity & \\
\hline NIM & Net Interest Margin & Net Interest Income / Average Total Assets & \\
\hline \multicolumn{4}{|c|}{ Independent Variables } \\
\hline \multicolumn{4}{|c|}{ Bank-specific Variables } \\
\hline LIQ & Liquidity Ratio & Total Loan/Total Assets & + \\
\hline $\mathrm{AQ}$ & Asset Quality & Loan Loss Provisions/Total Loan & - \\
\hline SZE & Bank Size & Natural log of Total Assets & + \\
\hline MEF & Management Efficiency & Total Expenses / Total Assets & + \\
\hline RSK & Risk & Total Equity/Total Assets & + \\
\hline \multicolumn{4}{|c|}{ Macroeconomic Variables } \\
\hline ECG & Economic Growth & Annual growth in GDP per Capita & + \\
\hline INF & Inflation Rate & Annual change in Price & - \\
\hline EXR & Exchange Rate & Natural logarithm of Real Exchange Rate Index & - \\
\hline BRM & Broad Money & M3 & + \\
\hline RQ & Regulatory Quality & Regulatory Quality Index & + \\
\hline
\end{tabular}

\section{METHODOLOGY}

\section{Data and sample}

The data for this study are sourced from the audited financial reports of four banks (ANZ, BSP, WESTPAC, and BOB), two credit financiers (MF and CC), and one housing bank (HFC) which later evolved into a fully-fledged commercial 
bank, available on the Reserve Bank of Fiji's website. The seven financial institutions reflect cross-sectional data while the time series is reflected by the 19 years under consideration.

\section{Model specification}

This study employs multivariate econometrics to analyse the determinants of bank profitability in Fiji using ROA and NIM as independent variables. Following Short (1979), Bourke (1989), and many others, we use the linear functional form of analysis, hence, the model is specified as follows:

$y_{j t}=\delta_{i}+\alpha_{i t}^{\prime} X_{i j t}+\varepsilon_{j t}$

where:

$j$ represents individual banks,

$t$ represents the year,

$y_{i t}$ refers to the profitability of bank $j$ at time $t$ and it is the observation of a bank's profitability in a particular year $t$,

$X_{i}$ refers to the bank-specific and macroeconomic determinants of a bank's profitability,

$\varepsilon_{j t}$ refers to the random error term.

Extending the above will provide our regression models as follows:

$$
\begin{aligned}
& R O A_{i t}=\delta_{0}+\alpha_{1} L I Q_{i t}+\alpha_{2} A Q+\alpha_{3} S Z E_{i t}+\alpha_{4} M E F_{i t}+\alpha_{5} R S K_{i t}+\alpha_{6} E C G_{i t}+\alpha_{7} I N F_{i t}+\alpha_{8} E X R_{i t}+\alpha_{9} B R M_{i t} \\
& +\alpha_{10} R Q_{i t}+\varepsilon_{i t} \\
& R O E_{i t}=\delta_{0}+\alpha_{1} L I Q_{i t}+\alpha_{2} A Q+\alpha_{3} S Z E_{i t}+\alpha_{4} M E F_{i t}+\alpha_{5} R S K_{i t}+\alpha_{6} E C G_{i t}+\alpha_{7} I N F_{i t}+\alpha_{8} E X R_{i t}+\alpha_{9} B R M_{i t} \\
& +\alpha_{10} R Q_{i t}+\varepsilon_{i t} \\
& N I M_{i t}=\delta_{0}+\alpha_{1} L I Q_{i t}+\alpha_{2} A Q+\alpha_{3} S Z E_{i t}+\alpha_{4} M E F_{i t}+\alpha_{5} R S K_{i t}+\alpha_{6} E C G_{i t}+\alpha_{7} I N F_{i t}+\alpha_{8} E X R_{i t}+\alpha_{9} B R M_{i t} \\
& +\alpha_{10} R Q_{i t}+\varepsilon_{i t}
\end{aligned}
$$

where:

$y_{i t}$ refers to the profitability of bank $i$ at time $t$ which is represented by ROA, ROE, and NIM, thus, three models will be tested against all independent variables described earlier in Table 1.

Equation 2 is estimated using the fixed effects model taking ROA, ROE, and NIM as dependent variables. Crosssectional correlation, heteroskedasticity, and autocorrelation problems are controlled using Driscoll and Kraay's (1998) standard errors while the option between random and fixed effects model is chosen based on the Hausman (Baltagi, $\underline{2005})$ test. The fixed-effects model is also supported by Baltagi (2005) for panel data analysis of a specific set of firms as is the case in this study which is based on seven specific banking institutions. Residual heteroskedasticity is checked for using the Breusch-Pagan/Cook-Weisberg test while multicollinearity is tested based on Gujarati (2007) and via correlation matrix.

\section{Estimation methodology}

There are several estimation methodologies available for estimating equations (1), (2), and (3), including Pooled Ordinary Least Squares (PLS) and panel data models. The PLS estimation pools together all data and applies ordinary least squares, reducing the cross-sections to a single unit, thereby, resulting in highly inaccurate standard errors in cases of any or all of the following: heteroskedasticity, cross-sectional correlation, and autocorrelation. The panel data models,

\begin{tabular}{|c|c|c|c|c|c|c|c|}
\hline \multicolumn{8}{|c|}{ Dependent Variable: Return on Average Assets (ROA) } \\
\hline & $\begin{array}{c}\text { F-Test for } \\
\text { FE }\end{array}$ & $\begin{array}{l}\text { BP LM Test } \\
\text { for } \mathbf{R E}\end{array}$ & $\begin{array}{c}\text { Hausman } \\
\text { Test }\end{array}$ & $\begin{array}{l}\text { FE v RE } \\
\text { OVERID }\end{array}$ & $\begin{array}{c}\text { BP LM } \\
\text { Test }\end{array}$ & $\begin{array}{c}\text { Modified Wald } \\
\text { Test }\end{array}$ & $\begin{array}{c}\text { Wooldridge } \\
\text { Test }\end{array}$ \\
\hline F Statistic & 24.15 & & & & & & 5.10 \\
\hline Chi $^{2}$ & & 47.50 & 59.06 & & 35.52 & 486.04 & \\
\hline $\begin{array}{l}\text { Sargan- } \\
\text { Hansen stat }\end{array}$ & & & & 116.31 & & & \\
\hline p-value & 0.00 & 0.00 & 0.00 & 0.00 & 0.02 & 0.00 & 0.06 \\
\hline \multicolumn{8}{|c|}{ Dependent Variable: Return on Average Equity (ROE) } \\
\hline F Statistic & 13.17 & & & & & & 24.68 \\
\hline
\end{tabular}
while allowing us to control for each financial institution's heterogeneity and temporal effects without aggregation bias, increase the accuracy of approximations.

Several tests are, therefore, applied to our panel data to choose the most appropriate model from different panel data models that are available. The results are presented in Table 2.s

Table 2: Results of diagnostic tests 


\begin{tabular}{|c|c|c|c|c|c|c|c|}
\hline $\mathrm{Chi}^{2}$ & & 0.00 & 48.85 & & 36.42 & 295.45 & \\
\hline $\begin{array}{l}\text { Sargan- } \\
\text { Hansen stat }\end{array}$ & & & & - & & & \\
\hline p-value & 0.00 & 1.00 & 0.00 & - & 0.02 & 0.000 & 0.003 \\
\hline \multicolumn{8}{|c|}{ Dependent Variable: Net Interest Margin (NIM) } \\
\hline F Statistic & 26.93 & & & & & & 4.75 \\
\hline $\mathrm{Chi}^{2}$ & & 68.87 & 58.53 & & 29.82 & 8.87 & \\
\hline $\begin{array}{l}\text { Sargan- } \\
\text { Hansen stat }\end{array}$ & & & & 143.16 & & & \\
\hline p-value & 0.00 & 0.00 & 0.00 & 0.00 & 0.10 & 0.26 & 0.07 \\
\hline
\end{tabular}

The joint F-test for joint significance of bank-specific fixed effects (FE) strongly supports fixed effects against the alternative of pooled regression for the three models. The Breusch and Pagan Lagrangian multiplier (BPLM) test for random effects (RE) is then carried out to further test whether PLS regression is preferred to RE. The test statistic is significant for Models (1) and (3) rejecting the null that PLS was appropriate. On the other hand, the test results for model (2) indicate the presence of random effects. The Hausman test is then carried out to compare the FE model with the RE model. The results in Table 2 support the use of FE model for our panel data analysis using the three models; however, the test results show that the variance of the estimated coefficients of the two estimates is not positively definite, thus, the over-identification test is carried out which rejects RE in favour of FE models for models (1) and (3), while for model (2), the test reveals that PLS is same as RE.

Furthermore, the Breusch-Pagan LM (Breusch \& Pagan, 1980) based on Baltagi et al. (2012) test of the correlation matrix of residuals reveals that the panel suffers from cross-sectional dependence in models (1) and (2). We used the Modified Wald (Baum, 2000) test for group-wise heteroskedasticity in our regression models and find that the panel suffers from heteroskedasticity when ROA is used as the predictor variable while models (2) and (3) suffer from no such problem. The Wooldridge (2002) test of our panel data reveals that the first-order autocorrelation is a problem in the model (2) only. Lastly, as per Table 3, the Harris \& Tzavalis (1999) test for unit root reveals that all variables are stationary, except for BRM. Levin-Lin-Chu's (2002) test is then applied which confirms the stationarity of BRM.

Table 3: Harris-Tzavalis and Levin-Lin-Chu Unit Root Test Results

\begin{tabular}{|c|c|c|c|c|}
\hline & \multicolumn{2}{|c|}{ Harris-Tzavalis } & \multicolumn{2}{|c|}{ Levin-Lin-Chu } \\
\hline & Level I & & Level I(0 & \\
\hline & Stat & p-value & Stat & p-value \\
\hline ROA & 0.5347 & 0.0000 & & \\
\hline ROE & 0.6640 & 0.0000 & & \\
\hline NIM & 0.5038 & 0.0000 & & \\
\hline AQ & 0.6733 & 0.0013 & & \\
\hline MEF & 0.5347 & 0.0000 & & \\
\hline RSK & 0.7447 & 0.0362 & & \\
\hline SZE & 0.6995 & 0.0051 & & \\
\hline BRM & 0.9650 & 0.9751 & $-2.9744^{*}$ & 0.0015 \\
\hline INF & 0.1125 & 0.0000 & & \\
\hline ECG & 0.1936 & 0.0000 & & \\
\hline RQ & 0.6325 & 0.0001 & & \\
\hline LIQ & 0.3432 & 0.0001 & & \\
\hline EXR & 0.6859 & 0.0026 & & \\
\hline
\end{tabular}

*Adjusted $t$

Furthermore, in order to deal with cross-sectional dependence, heteroskedasticity, and serial autocorrelation we rely on Driscoll and Kraay (1998) standard errors (DKSE) with FE (within) regression since this is expected to produce robust standard errors in the presence of problems as discussed earlier. According to Hoechle (2007), the Driscoll and Kraay technique produces heteroskedasticity consistent standard errors that are robust to very general forms of spatial and temporal dependence, estimated using a non-parametric covariance matrix. Also, as highlighted by Magee et al., (2021), this study is based on firms that operate in the same industry and are likely to have similar economic characteristics and, as a result, experience the same economic shocks. 


\section{RESULTS AND DISCUSSION}

\section{Descriptive analysis}

Table 4 provides a summary of descriptive statistics of all variables used in the regression model. The profitability measures of ROA, ROE, and NIM range between a minimum of $-0.631,-2.937$, and $0.013 \%$ and maximum values of $10.07 \%, 75.45 \%$, and $18.35 \%$ with a mean of $2.56 \%, 15.72 \%$, and $3.67 \%$ respectively exhibiting positive skewness distribution between 2001 and 2019. Positive means for all measures of profitability indicate that the banking institution in Fiji has done well despite economic challenges faced by the Fijian economy over the past two decades.

Table 4: Summary statistics

\begin{tabular}{llllll}
\hline Variable & Obs & Mean & Std. Dev. & Min & Max \\
\hline ROA & 133 & 3.825 & 2.563 & -0.631 & 10.07 \\
\hline ROE & 133 & 27.334 & 15.723 & -2.937 & 75.452 \\
\hline NIM & 133 & 7.321 & 3.661 & 0.013 & 18.346 \\
\hline LIQ & 133 & 6.998 & 7.354 & 0.017 & 32.892 \\
\hline AQ & 133 & 3.351 & 3.231 & 0.002 & 16.367 \\
\hline SZE & 133 & 19.741 & 1.263 & 17.294 & 21.846 \\
\hline MEF & 133 & 6.303 & 2.654 & 1.193 & 15.356 \\
\hline RSK & 133 & 13.907 & 8.233 & 3.149 & 38.362 \\
\hline ECG & 133 & 2.497 & 1.999 & -1.386 & 5.604 \\
\hline INF & 133 & 3.412 & 1.82 & 0.519 & 7.732 \\
\hline EXR & 133 & 4.701 & 0.051 & 4.605 & 4.785 \\
\hline BRM & 133 & 22.2 & 0.481 & 21.338 & 22.942 \\
\hline RQ & 133 & -0.415 & 0.231 & -0.958 & 0.076 \\
\hline
\end{tabular}

LIQ is one of the independent variables, which has a mean score of $6.99 \%$ with minimum and maximum values between $0.17 \%$ and $32.89 \%$ respectively. The result indicates some risk, however; the seven financial institutions are in a position to do well, even in times of economic downturns. The descriptive result of Asset Quality (AQ) depicts that some financial institutions were vigorous in assessing and advancing loans whereas some have not practiced proper due diligence in assessing loans and advances. The minimum and maximum stand between $0.002 \%$ and $16.37 \%$ respectively. SZE has a mean value of $19.7 \%$ and a standard deviation of $1.3 \%$, which indicates the seven chosen financial institutions are not much dispersed in terms of size. Management efficiency (MEF) on average is $6.30 \%$ with a standard deviation of $2.65 \%$ for seven financial institutions, indicating good management decision-making overall in reducing the cost of operations - which is ultimately good for profit generation. RSK measured by the ratio of total equity and total assets is more spread out from the mean with a standard deviation of $8.23 \%$ indicating wider differences among the seven financial institutions.

For all the macroeconomic determinants; ECG, INF, EXR, BRM, and RQ, the standard deviation is more concentrated around their respective mean scores indicating fewer differences and consistent performance over 19 years for the seven financial institutions.

\section{Correlation Analysis}

The problem of multicollinearity that may arise due to highly correlated independent variables was considered based on Dohoo et al. (1997), according to which, multicollinearity is highly problematic in the presence of a correlation coefficient of 0.9 or more. Pearson Correlation coefficients for our data are presented in Table 5 and show that the highest correlation coefficient is between MEF and AQ which is less than the threshold of 0.9, while the rest of the coefficients are well below this level, indicating the absence of a multicollinearity problem ensuring that the variables are independent of each other.

The correlation matrix also affirms, to a large extent, the absence of multicollinearity, based on Bryman and Cramer (2001), who postulate the presence of multicollinearity when the correlation index is 0.80 or more; however, a 0.80 correlation between MEF and AQ is of some concern.

Table 5: Correlation matrix

\begin{tabular}{|c|c|c|c|c|c|c|c|c|c|c|c|c|c|}
\hline Variables & ROA & ROE & NIM & LIQ & $\mathbf{A Q}$ & SZE & MEF & RSK & ECG & INF & EXR & BRM & RQ \\
\hline ROA & 1.000 & & & & & & & & & & & & \\
\hline ROE & 0.243 & 1.000 & & & & & & & & & & & \\
\hline NIM & 0.788 & 0.110 & 1.000 & & & & & & & & & & \\
\hline LIQ & 0.332 & -0.219 & 0.242 & 1.000 & & & & & & & & & \\
\hline $\mathbf{A Q}$ & 0.573 & -0.247 & 0.630 & 0.336 & 1.000 & & & & & & & & \\
\hline SZE & -0.395 & 0.321 & -0.589 & -0.146 & -0.685 & 1.000 & & & & & & & \\
\hline
\end{tabular}




\begin{tabular}{|c|c|c|c|c|c|c|c|c|c|c|c|c|c|}
\hline MEF & 0.387 & -0.364 & 0.501 & 0.262 & 0.805 & -0.677 & 1.000 & & & & & & \\
\hline RSK & 0.740 & -0.362 & 0.679 & 0.412 & 0.633 & -0.579 & 0.546 & 1.000 & & & & & \\
\hline ECG & -0.051 & -0.075 & -0.088 & 0.106 & -0.134 & 0.187 & -0.204 & -0.046 & 1.000 & & & & \\
\hline INF & 0.009 & -0.041 & 0.076 & 0.108 & 0.013 & -0.085 & 0.157 & 0.073 & -0.339 & 1.000 & & & \\
\hline EXR & 0.085 & 0.244 & 0.050 & -0.086 & 0.077 & -0.087 & 0.016 & -0.115 & -0.268 & 0.220 & 1.000 & & \\
\hline BRM & -0.057 & -0.314 & -0.224 & 0.237 & -0.350 & 0.430 & -0.387 & 0.158 & 0.292 & -0.111 & -0.170 & 1.000 & \\
\hline RQ & -0.113 & 0.032 & -0.120 & -0.052 & 0.048 & 0.037 & 0.036 & -0.188 & 0.268 & -0.319 & 0.130 & -0.055 & 1.000 \\
\hline
\end{tabular}

Hence, the VIF test, based on Gujarati (2007) and Hung et al. (2010) is carried out to further study the issue of multicollinearity in our panel data. The results provided in Table 6 indicate that the data is free of the multicollinearity problem as the mean and individual VIF is well below the maximum acceptable Variance Inflation Factor of 10 (Hair et al., 1998).

Table 6: Variance inflation factor

\begin{tabular}{lll}
\hline & VIF & 1/VIF \\
\hline AQ & 4.207 & .238 \\
\hline MEF & 3.549 & .282 \\
\hline RSK & 3.498 & .286 \\
\hline SZE & 2.839 & .352 \\
\hline BRM & 2.399 & .417 \\
\hline INF & 1.396 & .717 \\
\hline ECG & 1.394 & .717 \\
\hline RQ & 1.367 & .732 \\
\hline LIQ & 1.358 & .737 \\
\hline EXR & 1.278 & .782 \\
\hline MEAN VIF & 2.329 & \\
\hline
\end{tabular}

\section{Panel Regression Analysis}

Using ROA, ROE, and NIM as the dependent variables and the same 10 independent variables we estimate the three models using FE, methodologies, with results provided in Table 7.

Table 7: Panel regression analysis

\begin{tabular}{|c|c|c|c|c|c|c|}
\hline & \multicolumn{2}{|c|}{ Return on Average Assets } & \multicolumn{2}{|c|}{ Return on Average Equity } & \multicolumn{2}{|c|}{ Net interest Margin } \\
\hline & FE & FE with DKSE & FE & FE with DKSE & FE & FE with DKSE \\
\hline \multirow[t]{2}{*}{ LIQ } & 0.023 & 0.023 & 0.259 & $0.259 *$ & 0.015 & 0.015 \\
\hline & $(0.0156)$ & $(0.0164)$ & $(0.1410)$ & $(0.0994)$ & $(0.0248)$ & $(0.0224)$ \\
\hline \multirow[t]{2}{*}{$\mathbf{A Q}$} & -0.093 & -0.093 & $-1.409 *$ & -1.409 & $-0.236^{*}$ & -0.236 \\
\hline & $(0.0643)$ & $(0.1433)$ & $(0.5812)$ & $(0.7039)$ & $(0.1024)$ & $(0.1361)$ \\
\hline \multirow[t]{2}{*}{ SZE } & $1.430 * * *$ & $1.430 * * *$ & $7.370 * * *$ & $7.370^{* * *}$ & $2.176^{* * *}$ & $2.176^{* * *}$ \\
\hline & $(0.2327)$ & $(0.2433)$ & $(2.1041)$ & $(1.8358)$ & $(0.3706)$ & $(0.2031)$ \\
\hline \multirow[t]{2}{*}{ MEF } & $-0.372 * * *$ & $-0.372 * *$ & $-2.598 * *$ & $-2.598 * *$ & 0.068 & 0.068 \\
\hline & $(0.0862)$ & $(0.1076)$ & $(0.7798)$ & $(0.7015)$ & $(0.1373)$ & $(0.1452)$ \\
\hline \multirow[t]{2}{*}{ RSK } & $0.173 * * *$ & $0.173 * * *$ & -0.222 & -0.222 & $0.258 * * *$ & $0.258 * * *$ \\
\hline & $(0.0287)$ & $(0.0458)$ & $(0.2596)$ & $(0.2445)$ & $(0.0457)$ & $(0.0456)$ \\
\hline \multirow[t]{2}{*}{ ECG } & -0.047 & -0.047 & -0.440 & -0.440 & 0.047 & 0.047 \\
\hline & $(0.0524)$ & $(0.0237)$ & $(0.4742)$ & $(0.2693)$ & $(0.0835)$ & $(0.0463)$ \\
\hline \multirow[t]{2}{*}{ INF } & -0.069 & -0.069 & -0.751 & $-0.751 *$ & -0.059 & -0.059 \\
\hline & $(0.0586)$ & $(0.0593)$ & $(0.5301)$ & $(0.3177)$ & $(0.0934)$ & $(0.0546)$ \\
\hline EXR & $6.870 * * *$ & $6.870 * *$ & $61.528^{* *}$ & $61.528 * * *$ & $7.905^{*}$ & $7.905 * * *$ \\
\hline , & $(2.0298)$ & $(2.3096)$ & $(18.3509)$ & $(13.8366)$ & $(3.2320)$ & $(1.5795)$ \\
\hline \multirow[t]{2}{*}{ BRM } & $-3.340 * * *$ & $-3.340 * * *$ & $-26.413 * * *$ & $-26.413^{* * *}$ & $-5.275^{* * *}$ & $-5.275 * * *$ \\
\hline & $(0.3900)$ & $(0.4744)$ & $(3.5257)$ & $(3.5525)$ & $(0.6209)$ & $(0.5459)$ \\
\hline \multirow[t]{2}{*}{ RQ } & -0.761 & $-0.761 * *$ & -3.736 & -3.736 & $-1.507^{*}$ & $-1.507 * * *$ \\
\hline & $(0.4386)$ & $(0.2481)$ & $(3.9652)$ & $(3.0770)$ & $(0.6984)$ & $(0.3081)$ \\
\hline
\end{tabular}




\begin{tabular}{lllllll}
\hline CONSTANT & 17.560 & 17.560 & $203.441^{*}$ & $203.441^{*}$ & $40.434^{*}$ & $40.434^{* *}$ \\
\hline & $(11.9509)$ & $(11.2274)$ & $(108.0456)$ & $(88.9021)$ & $(19.0296)$ & $(12.1853)$ \\
\hline & 51.65 & & & & \\
\hline R-squared & 0.52 & 0.52 & 0.49 & 0.49 & 0.48 & 0.48 \\
\hline Adj. R-sq & 0.46 & & 0.42 & & 0.40 & \\
\hline Sten
\end{tabular}

Standard errors in parentheses

$* * * \mathrm{p}<0.01, * * \mathrm{p}<0.05, * \mathrm{p}<0.1$

Overall, the R-squares reveal that the internal and macroeconomic determinants of bank profitability explain approximately $52 \%$ of the variations in ROA, $49 \%$ of the variations in ROE, and $48 \%$ of the variations in NIM. There is a slight loss in the goodness of fit for all the three models revealed by adjusted R-square of 0.46 for ROA, 0.42 for ROE, and 0.40 for NIM.

\section{Bank-level determinants}

According to the results provided in Table 5, LIQ is found to have a positive relationship with all measures of profitability but is statistically significant, at a $10 \%$ significance level, only in the case of ROE, hence, our hypothesis $\mathrm{H}_{1}$ is accepted. This is consistent with Bourke (1989), Abreu and Mendes (2002), Yao et al. (2018), and Al-Matari (2021) who reported that higher liquidity in the banking system fosters opportunities for more profit-generating activities, but is inconsistent with Hakimi and Zaghdoudi (2017) and Godfrey (2015), who argue that high levels of liquidity may reduce profitability as banks are forced to lend at lower interest rates.

The second independent variable, AQ, is found to have a statistically insignificant negative relationship with ROA but a similar relationship is found to be statistically significant at a $10 \%$ level with ROE and NIM, verifying our hypothesis $\mathrm{H}_{2}$, and is in agreement with the findings reported by Kadioglu et al. (2017), Yao et al. (2018), Sultan et al. (2020) and others. The empirical evidence suggests that banks seem to suffer significantly from high-risk lending, which has resulted in a loss in revenue and higher expenditure due to higher-than-expected bad and doubtful debts.

The impact of bank size (SZE) is found to be positive and statistically significant on all three measures of profitability which is in agreement with the findings reported by Hashem (2016), Gaber (2018), Sultan et al. (2020), and Kumar et al.

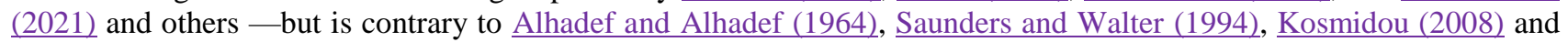
Berger (1995). Hence, our hypothesis $\mathrm{H}_{3}$ is accepted. The empirical evidence suggests that the banks exploit their size to generate higher levels of profitability, thus validating the importance of economies of scale in achieving better financial performance.

The results for MEF show that there is a statistically significant negative relationship between MEF and ROA and MEF and ROE indicating the high cost of managerial decision-making resulting in a negative impact on returns on assets and equity, thus we accept our $\mathrm{H}_{4}$. However, it has a positive and statistically insignificant impact on NIM. This shows that banks in Fiji effectively pass on the high cost of their operations to their customers via high margin lending; however, any resulting gains are more than offset by losses arising from non-lending activities. The findings of this study agree with the findings reported by Goddard et al. (2004), Gaber (2018), Abdullah et al. (2014), Khediri and Ben-Khedhiri (2011), and Kumar et al. (2021) - however, they disagree with the earlier results reported by Sharma and Gounder (2012). The results, therefore, invalidate our hypothesis $\mathrm{H}_{4}$.

Finally, in line with the findings reported by Abdullah et al. (2014), Sanni et al. (2020), and Kumar et al. (2021), RSK seems to have a positive and statistically significant relationship with ROA and NIM indicating that banks can generate significant profits from taking lower levels of risks. A negative and insignificant relationship with ROE is normal since higher equity will have a positive impact on the RSK ratio but a negative impact on return on average equity. Thus, we accept our hypothesis $\mathrm{H}_{5}$.

\section{Macroeconomic determinants}

From the five variables used in this study, BRM and EXR are found to be statistically significant (at a 5\% significance level) in determining the profitability of banks under all estimation techniques. EXR is found to have a positive relationship with profitability measures and is statistically significant, contrary to the results obtained by Manyok (2016), Elhussein and Onsma (2019), Hossin and Mondol (2020), Faroog et al. (2021), and Ozkan (2021), thus we reject our hypothesis $\mathrm{H}_{8}$. The result indicates that banks can exploit fluctuations in the foreign exchange rate to make significant gains from dealing in foreign currencies and/or using foreign borrowed funds to generate income locally. On the other hand, BRM is found to have a negative and significant relationship with profitability and, in agreement with the findings reported by Borio et al. (2017), validating our hypothesis $\mathrm{H}_{9}$. The evidence indicates that growth in broad money supply tends to reduce bank profitability as it tends to lower lending interest rates which substantially diminishes bank profits.

Economic growth, measured as the percentage change in real GDP, is found to have a negative and insignificant relationship with ROA and ROE but a positive and insignificant relationship with NIM. The results presented in this study, in line with the findings reported in Staikouras and Wood (2004), Demirguc-Kunt and Huizinga (1999), Bourke (1989), and Sufian and Chong (2008) indicate that banks in Fiji, to a large extent, are not significantly harmed by 
downturns in the local economy. In fact, the results indicate they do better during economic downturns compared to their performance during economic growth. Thus, we reject our hypothesis $\mathrm{H}_{6}$.

Furthermore, the results of our study show that inflation (INF) has a negative and insignificant relationship with ROA and NIM but a negative and significant (at 10\%) relationship with ROE. The results of this study are in agreement with the findings reported by Ayaydin and Aykut (2014), Yao et al. (2018), Quan et al. (2019), Sultan et al. (2020), and Faroog et al. (2021). This indicates that rising inflation tends to increase defaults and loan terminations resulting in loss of revenue via bad and doubtful debts, hence we accept our $\mathrm{H}_{7}$.

Lastly, the evidence from this study shows that the quality of regulation (RQ) has a negative and significant relationship with ROA and NIM but a negative and insignificant relationship with ROE indicating that poor quality of regulation in the country provides opportunities for the banking system to make more profit. Poor quality of regulation seems to give opportunities for banks to engage in unfair banking practices that are costly for the customers but beneficial to the bank. While strong regulations may exist, implementing them may be an issue given the lack of resources and expertise available with the regulatory authorities. The findings of this study tend to disagree with the findings reported by Nguyen et al. (2015), Ngobo and Fouda (2012), Aguilera and Jackson (2010), and Filatotchev et al. (2013), thus we reject $\mathrm{H}_{10}$.

\section{CONCLUSION}

This study aimed to examine the impact of various internal and macroeconomic factors on the financial performance of banks in Fiji. Data from audited annual financial statements of five commercial banks and two credit banks within the period 2001-2019 were used to conduct the study. We employed the fixed-effects model to estimate the parameters of our three models and Driscoll-Kraay standard errors to control for cross-sectional correlation, heteroskedasticity, and first-order autocorrelation in the data.

Overall results affirm the importance of bank-specific and macroeconomics factors in explaining the profitability in Fiji's banks. Bank-specific variables such as bank size and risk show positive relationships with bank performance. Positive relationships of bank size with ROA, ROE, and NIM suggest that the banks in Fiji exploit their size to generate higher levels of profitability. The positive relationship of risk with ROA and NIM implies that banks can generate significant profits from taking lower levels of risks. The negative relationship of management efficiency with ROA and ROE shows effective passing on of the high costs of banks' operations to their customers via high margin lending; however, any resulting gains are more than offset by losses arising from non-lending activities. On the other hand, macroeconomic determinants, broad money supply, quality of regulation, and economic growth have a negative relationship with bank performance. The negative relationship between broad money supply and profitability indicates that growth in broad money supply tends to reduce bank profitability as it tends to lower lending interest ratessubstantially diminishing bank profits. A negative relationship between quality of regulation and profitability is plausible when poor quality of regulation in the country provides opportunities for the banking system to make more profits. Finally, the negative association of economic growth with bank profit indicates that banks in Fiji, to some extent, are not significantly harmed by downturns in the local economy. Only exchange rates seem to have a positive relationship with profitability measures, which indicates that Fijian banks can exploit changes in the exchange rate to make significant gains from dealing in foreign currencies and/or using foreign borrowed funds to generate income locally.

\section{RECOMMENDATIONS}

The findings of this study have some notable implications. Firstly, to improve performance, banks need to achieve economies of scale and significantly reduce the total cost of providing bank services to improve their financial performance. Secondly, there is a need for a better quality of regulation in the economy to reduce opportunities for banks to exploit their customers. Exploitative practices of banks could trigger government intervention which could reduce profits significantly in the future.

\section{LIMITATIONS}

Given that this research does suffer from inherent limitations, further studies should focus on a larger sample size as well as a longer time horizon, which would permit the use of different data analysis methodologies to be applied to the data set.

\section{FUTURE DIRECTIONS}

Future studies should focus on a mixed-methods approach, which will allow qualitative determinants to be considered as independent variables in determining bank profitability. Also, future research should consider more variables related to banks, the banking industry, and the economy.

\section{CONTRIBUTIONS}

Bimal Krishna conceived the entire study and undertook data transcribing, analysis and interpretation. Mr. Shiu Lingam assisted in referencing and the literature review. Ms. Anajani Mala assisted in descriptive statistics analysis 
and the introduction. Mr. Rajit Sen was involved in the literature review, hypothesis development, and critical revision of the article. All authors have read and approved the final copy of the manuscript.

\section{REFERENCES}

1. Abdullah, M. N., Parvez, K., Akther, S., \& Ayreen, S. (2014). Bank specific, industry specific and macroeconomic determinants of commercial bank profitability: A case of Bangladesh. World Journal of Social Sciences, 4(3), 82-96. https://doi.org/10.18488/journal.1006.2019.92.174.183

2. Abreu, M., \& Mendes, V. (2002). Commercial bank interest margins and profitability: Evidence from some EU countries. Pan-European Conference Jointly Organised by the IEFS-UK \& University of Macedonia Economic \& Social Sciences, Thessaloniki, Greece, May, JANUARY, 1-11. http://www.iefs.org.uk/Papers/Abreu.pdf

3. Aguilera, R. V., \& Jackson, G. (2010). Comparative and international corporate governance. Academy of Management Annals, 4(1), 485-556. https://doi.org/10.1080/19416520.2010.495525

4. Alhadeff, D., \& Alhadeff, C. (1964). Growth of large banks, 1930-1960. The Review of Economics and Statistics, 46(4), 356-363.

5. Al-Matari, E. M. (2021). The determinants of bank profitability of GCC: The role of bank liquidity as moderating variable-further analysis. International Journal of Finance and Economics, August 2020, 1-13. https://doi.org/10.1002/ijfe.2485

6. Athanasoglou, P. P., Brissimis, S. N., \& Delis, M. D. (2008). Bank-specific, industry-specific and macroeconomic determinants of bank profitability. Journal of International Financial Markets, Institutions and Money, 18(2). https://doi.org/10.1016/j.intfin.2006.07.001

7. Ayaydin, H., \& Aykut, K. (2014). The effect of bank capital on profitability and risk in Turkish banking. International Journal of Business and Social Science, 5(1). http://www.ijbssnet.com/journals/Vol 5 N o_1 January 2014/29.pdf

8. Baltagi, B. H. (2005). Econometric analysis of panel data. John Wiley \& Sons Inc.

9. Baltagi, B. H., Feng, Q., \& Kao, C. (2012). A Lagrange Multiplier test for cross-sectional dependence in a fixed effects panel data model. Journal of Econometrics, 170(1), 164-177. https://doi.org/10.1016/j.jeconom .2012 .04 .004

10. Bashir, A.-H. (2003). Determinants of profitability in Islamic banks: Some evidence from the Middle-East. Islamic Economic Studies, 11-1(March), 32-57.

11. Baum, C. F. (2000). XTTEST3: Stata module to compute Modified Wald statistic for groupwise heteroskedasticity. Statistical Software Components, November 2000. https://ideas.repec.org/c/boc/ bocode/s414801.html

12. Berger, A. N. (1995). The profit-structure relationship in banking - tests of market-power and efficient-structure hypotheses. Journal of Money, Credit and Banking, 27(2). https://doi.org/10.2307/2077876

13. Borio, C., Gambacorta, L., \& Hofmann, B. (2015). The influence of monetary policy on bank profitability. International Finance, 20(1), 48-63. https://doi.org/https://doi.org/10.1111/infi.12104

14. Bourke, P. (1989). Concentration and other determinants of bank profitability in Europe, North America and Australia. Journal of Banking \& Finance, 13(1). https://doi.org/10.1016/0378-4266(89)90020-4

15. Breusch, T. S., \& Pagan, A. R. (1980). The Lagrange Multiplier Test and its applications to model specification in econometrics. The Review of Economic Studies, 47(1), 239-253. https://doi.org/10.2307/2297111

16. Bryman, A., \& Cramer, D. (2001). Quantitative data analysis with SPSS release 10 for windows: A guide for social scientists. In quantitative data analysis with SPSS release 10 for windows: A guide for social scientists. Routledge. https://doi.org/10.4324/9780203471548

17. Demirguc-Kunt, A., \& Huizinga, H. (1999). Determinants of commercial bank interest margins and profitability: Some international evidence. The World Bank Economic Review, 13(2). https://doi.org/10.109 3/wber/13.2.379

18. Dohoo, I. R., Ducrot, C., Fourichon, C., Donald, A., \& Hurnik, D. (1997). An overview of techniques for dealing with large numbers of independent variables in epidemiologic studies. Preventive Veterinary Medicine, 29(3), 221-239. https://doi.org/10.1016/s0167-5877(96)01074-4

19. Driscoll, J., \& Kraay, A. (1998). Consistent covariance matrix estimation with spatially dependent panel data. The Review of Economics and Statistics, 80(4), 549-560. https://econpapers.repec.org/RePEc:tpr:rest at:v:80:y:1998:i:4:p:549-560

20. Elhussein, N. H. A., \& Onsma, O. E. E. (2019). Exchange rate fluctuations and financial performance of banks: Evidence from Sudan. International Journal of Economics and Finance, 11(12), 15. https://doi.org/10.553 9/ijef.v11n12p15

21. Farooq, M., Khan, S., Atique Siddiqui, A., Tariq Khan, M., \& Kamran Khan, M. (2021). Determinants of profitability: A case of commercial banks in Pakistan. Humanities \& Social Sciences Reviews, 9(2), 01-13. https://doi.org/10.18510/hssr.2021.921

22. Filatotchev, I., Jackson, G., \& Nakajima, C. (2013). Corporate governance and national institutions: A review and emerging research agenda. Asia Pacific Journal of Management, 30(4), 965-986. https://doi.org/10.1007/s1 $\underline{0490-012-9293-9}$ 
23. Friedman, M. (1970). A Friedman doctrine - The Social responsibility of business is to increase its profits. New York Times Magazine, 6(Newspaper Article).

24. Gaber, A. (2018). Determinants of banking sector profitability: Empirical evidence from Palestine. International Journal of Economics and Finance, 9(7), 60-68.

25. Goddard, J. A., Molyneux, P., \& Wilson, J. O. S. (2004). Dynamics of growth and profitability in banking. Journal of Money, Credit, and Banking, 36(6). https://doi.org/10.1353/mcb.2005.0015

26. Godfrey, M. (2015). Liquidity and bank performance. International Business \& Economics Research Journal (IBER), 14(3), 453. https://doi.org/10.19030/iber.v14i3.9218

27. Gujarati, D. N. (2007). Basic Econometrics. Tata McGraw-Hill.

28. Hadri, K. (2000). Testing for stationarity in heterogeneous panel data. The Econometrics Journal, 3(2), 148161. https://doi.org/https://doi.org/10.1111/1368-423X.00043

29. Hair, J. F., Anderson, R. E., Tatham, R. L., \& Black, W. C. (1998). Multivariate data analysis with readings. Prentice Hall.

30. Hakimi, A., \& Zaghdoudi, K. (2017). Liquidity risk and bank performance: An empirical test for Tunisian banks. Business and Economic Research, 7(1), 46. https://doi.org/10.5296/ber.v7i1.10524

31. Harris, R., \& Tzavalis, E. (1999). Inference for unit roots in dynamic panels where the time dimension is fixed. Journal of Econometrics, 91(2), 201-226. https://econpapers.repec.org/RePEc:eee:econom:v:91:y:1999:1:2:p:201-226

32. Hashem, H. Y. (2016). Determinants of Egyptian banking sector profitability: Time-series analysis from 20042014. International Journal of Business and Economic Sciences Applied Research, 9(2), 73-78. https://doi.org/10.5539/ijef.v9n7p60

33. Hassan, M. K., \& Bashir, A.H. M. (2012). Determinants of Islamic banking profitability. In Islamic Perspectives on Wealth Creation (Issue April 2014). https://doi.org/10.3366/edinburg $\underline{\mathrm{h} / 9780748621002.003 .0008}$

34. Hoechle, D. (2007). Robust standard errors for panel regressions with cross-sectional dependence. The Stata Journal: Promoting Communications on Statistics and Stata, 7(3). https://doi.org/10.1177/1536867X0700700301

35. Hoffmann, P. S. (2011). Determinants of the profitability of the US banking industry. International Journal of Business and Social Science, 2(22). http://www.ijbssnet.com/journals/Vol_2_No_22_December_2011/30.pdf

36. Hossin, M. S., \& Mondol, M. F. (2020). Impact of exchange rate fluctuations on financial performance of stateowned commercial banks in Bangladesh: An empirical study. Noble International Journal of Economics and Financial Research, 5(September), 92-101.

37. Hung, W.T., Shang, J.K., \& Wang, F.C. (2010). Pricing determinants in the hotel industry: Quantile regression analysis. International Journal of Hospitality Management, 29(3), 378-384. https://doi.org/https://doi.org /10.1016/j.ijhm.2009.09.001

38. Jensen, M. (2001). Value maximisation, stakeholder theory, and the corporate objective function. European Financial Management, 7(3). https://doi.org/10.1111/1468-036X.00158

39. Kadioglu, E., Telceken, N., \& Ocal, N. (2017). Effect of the asset quality on the bank profitability. International Journal of Economics and Finance, 9(7), 60. https://doi.org/10.5539/ijef.v9n7p60

40. Khediri, K., \& Ben-Khedhiri, H. (2011). Determinants of bank net interest margin in Tunisia: A panel data model. Applied Economics Letters, 18(13), 1267-1271. https://doi.org/10.1080/13504851.2010.534052

41. Khrawish, H. A. (2011). Determinants of commercial banks performance: evidence from Jordan. International Research Journal of Finance and Economics, 5(5), 19-45.

42. Kosmidou, K. (2008). The determinants of banks' profits in Greece during the period of EU financial integration. Managerial Finance, 34(3). https://doi.org/10.1108/03074350810848036

43. Kumar, V., Thrikawala, S., \& Acharya, S. (2021). Financial inclusion and bank profitability: Evidence from a developed market. Global Finance Journal, 100609. https://doi.org/https://doi.org/10.1016/j.gfj.2021.100609

44. Levin, A., Lin, C. F., \& Chu, C. S. J. (2002). Unit root tests in panel data: Asymptotic and finite-sample properties. Journal of Econometrics, 108(1), 1-24. https://doi.org/10.1016/S0304-4076(01)00098-7

45. Magee, S., Man, C., \& Wright, S. (2021). How executive remuneration responds to guidance: Evidence from the Australian banking industry. Accounting and Finance, 60(5). https://doi.org/10.1111/acfi.12758

46. Maiti, A., \& Jana, K. S. (2017). Determinants of profitability of banks in India: A panel data analysis. Scholars Journal of Economics, Business and Management, 4(8A). https://doi.org/DOI:10.21276/sjebm

47. Mansur, I., Zangeneh, H., \& Zitz, M. S. (1993). The association between banks' performance ratios and marketdetermined measures of risk. Applied Economics, 25(12), 1503-1510. https://doi.org/10.1080/0003684 $\underline{9300000154}$

48. Manyok, A. J. (2016). Effects of exchange rate fluctuations on financial performance of commercial banks in South Sudan [Masters dissertation, University of Nairobi]

http://erepository.uonbi.ac.ke/bitstream/handle/11295/99547/Manyok_Effects\%20of\%20Exchange\%20Rate\%2 0Fluctuations\%20on\%20Financial\%20Performance\%20of\%20Commercial\%20Banks\%20in\%20South\%20Sud an.pdf?sequence $=1$ 
49. Mendoza, R., \& Rivera, J. P. R. (2017). The effect of credit risk and capital adequacy on the profitability of rural banks in the Philippines. Scientific Annals of Economics and Business, 64(1), 83-96. https://doi.org/10 $.1515 / \mathrm{saeb}-2017-0006$

50. Menicucci, E., \& Paolucci, G. (2016). The determinants of bank profitability: Empirical evidence from European banking sector. Journal of Financial Reporting and Accounting, 14(1), 86-115. https://doi.org/ 10.1108/JFRA-05-2015-0060

51. Miller, S. M., \& Noulas, A. G. (1997). Portfolio mix and large-bank profitability in the USA. Applied Economics, 29(4). https://doi.org/10.1080/000368497326994

52. Molyneux, P., \& Thornton, J. (1992). Determinants of European bank profitability: A note. Journal of Banking \& Finance, 16(6), 1173-1178. https://econpapers.repec.org/RePEc:eee:jbfina:v:16:y:1992:i:6:p:1173-1178

53. Naceur, S. Ben, \& Omran, M. (2011). The effects of bank regulations, competition, and financial reforms on banks' performance. Emerging Markets Review, 12(1). https://doi.org/10.1016/j.ememar.2010.08.002

54. Ngobo, P. V., \& Fouda, M. (2012). Is "Good" governance good for business? A cross-national analysis of firms in African countries. Journal of World Business, 47(3), 435-449. https://doi.org/10.1016/j.jwb.2011.05.010

55. Nguyen, T., Locke, S., \& Reddy, K. (2015). Ownership concentration and corporate performance from a dynamic perspective: Does national governance quality matter? International Review of Financial Analysis, 41 148-161. https://doi.org/https://doi.org/10.1016/j.irfa.2015.06.005

56. Obamuyi, T. M. (2013). Determinants of banks' profitability in a developing economy: Evidence from Nigeria. Organizations and Markets in Emerging Economies, 4(2), 97-111. https://doi.org/10.15388/omee.2 $\underline{013.4 .2 .14251}$

57. Ongore, V. O., \& Kusa, G. B. (2013). Determinants of financial performance of commercial banks in Kenya. International Journal of Economics and Financial Issues, 3(1), 237-252.

58. Özkan, Ö. (2021). Analysis Of the macroeconomic factors determining the asset profitability of the Turkish banking system in the period of 2010-2020. Journal of Accounting, Finance and Auditing Studies, 7(2), 64-79. https://doi.org/10.32602/jafas.2021.013

59. Pasiouras, F., \& Kosmidou, K. (2007). Factors influencing the profitability of domestic and foreign commercial banks in the European Union. Research in International Business and Finance, 21(2). https://doi.org/1 0.1016/j.ribaf.2006.03.007

60. Quan, L. J., Ramasamy, S., Rasiah, D., Yen, Y. Y., \& Pillay, S. D. (2019). Determinants of Islamic banking performance: An empirical study in Malaysia (2007 to 2016). Humanities and Social Sciences Reviews, 7(6), 380-401. https://doi.org/10.18510/hssr.2019.7664

61. Rahman, M. M., Hamid, M. K., \& Khan, M. A. M. (2015). Determinants of bank profitability: Empirical evidence from Bangladesh. International Journal of Business and Management, 10(8). https://doi.org /10.5539/ijbm.v10n8p135

62. Sahyouni, A., \& Wang, M. (2019). Liquidity creation and bank performance: Evidence from MENA. ISRA International Journal of Islamic Finance, 11(1), 27-45. https://doi.org/10.1108/IJIF-01-2018-0009

63. Sanni, M., Salami, A. A., \& Uthman, A. B. (2020). Determinants of bank performance in Nigeria: do they behave differently with risk-adjusted returns? Studia Universitatis Vasile Goldis Arad - Economics Series, 30(3), 1-34. https://econpapers.repec.org/RePEc:vrs:suvges:v:30:y:2020:i:3:p:1-34:n:1

64. Saunders, A., \& Walter, I. (1994). Universal banking in the United States: What could we gain? What could we lose? Southern Economic Journal, 61(1), 231. https://doi.org/10.2307/1060155

65. Sharma, P., \& Gounder, N. (2012). Profitability determinants of deposit institutions in small, underdeveloped financial systems: The case of Fiji. SSRN Electronic Journal. https://doi.org/10.2139/ssrn.2187251

66. Short, B. K. (1979). The relation between commercial bank profit rates and banking concentration in Canada, Western Europe, and Japan. Journal of Banking and Finance, 3(3), 209-219. https://doi.org/10.1016/03784266(79)90016-5

67. Smirlock, M. (1985). Evidence on the (Non) Relationship between concentration and profitability in Banking. Journal of Money, Credit and Banking, 17(1), 69-83. https://doi.org/10.2307/1992507

68. Srairi, S. A. (2009). Factors influencing the profitability of conventional banks and Islamic banks in GCC countries. Review of Islamic Economics, 13(1), 5-30.

69. Staikouras, C. K., \& Wood, G. E. (2004). The determinants of European bank profitability. International Business \& Economics Research Journal (IBER), 3(6), 57-68. https://doi.org/10.19030/iber.v3i6.3699

70. Sufian, F. (2009). Determinants of bank profitability in a developing economy: Empirical evidence from the china banking sector. Journal of Asia-Pacific Business, 10(4). https://doi.org/10.1080/10599230903340205

71. Sufian, F., \& Chong, R. R. (2008). Determinants of bank profitability in a developing economy: Empirical evidence from the philipinnes. Asian Academy of Management Journal of Accounting and Finance (AAMJAF), 4(2), 91-112. https://ideas.repec.org/a/usm/journl/aamjaf00402_91-112.html

72. Sultan, K., Ahmed, R. R., Ameen, F. M., Kumar, D., \& Singh, M. (2020). The effect of macroeconomic \& bank specific factors on banks profitability: An empirical evidence from banking industry of Pakistan. Humanities and Social Sciences Reviews, 8(3), 635-645. https://doi.org/10.18510/HSSR.2020.8368 
73. Tabak, B. M., Moreira, T. B. S., Fazio, D. M., Cavalcanti, A. L. C., \& De Moura Cunha, G. H. (2016). Monetary expansion and the banking lending channel. PLOS ONE, 11(10). https://doi.org/10.1371/journ al.pone.0164338

74. Tan, Y., \& Floros, C. (2012). Bank profitability and inflation: The case of China. Journal of Economic Studies, 39(6), 675-696. https://doi.org/10.1108/01443581211274610

75. Tektas, A., Ozkan-Gunay, E. N., \& Gunay, G. (2005). Asset and liability management in financial crisis. The Journal of Risk Finance, 6(2), 135-149. https://doi.org/10.1108/15265940510585806

76. Uwazie, I. U., \& Aina, T. H. (2015). Monetary policy variables and commercial bank loans: A causality approach. Research Journal of Finance and Accounting, 6, 35-42.

77. Wong, T. C., Wong, J., \& Leung, P. (2008). The foreign exchange exposure of Chinese banks. China Economic Review, 20(2). https://doi.org/10.2139/ssrn.1485198

78. Wooldridge, J. (2002). Econometric Analysis of Cross Section and Panel Data. The MIT Press.

79. Yao, H., Haris, M., \& Tariq, G. (2018). Profitability determinants of financial institutions: evidence from banks in Pakistan. International Journal of Financial Studies, 6(2), 53. https://doi.org/10.3390/ijfs6020053 